\title{
POZNÁMKA K MERLEAU-PONTYHO TEXTU VNÍMÁNÍ DRUHÉHO A DIALOG
}

Ústředním tématem výše publikovaného textu je vztah $\mathrm{k}$ druhým. ${ }^{1}$ Merleau-Ponty nicméně začíná velmi obecnou úvahou o řeči a v závěru se k ní opět vrací. Je to dáno skutečností, že jde o jednu kapitolu rukopisu knihy Próza světa, na níž Merleau-Ponty pracoval od konce 40. let a kterou v nedokončené podobě odložil na přelomu let 1951 a $1952 .{ }^{2}$ Jednotícím tématem této knihy je právě řeč, přesněji řečeno tvůrčí výraz. Slovy „tvưrčí“ či ,zdařilý výraz“ Merleau-Ponty chápe takové vyjádření, které se neomezuje na zavedené užití jazykových prostředků, nýbrž je promění. Pro Merleau-Pontyho je přitom důležité, že změna se týká nejen způsobu, jímž mluvíme, ale i způsobu, jak zakoušíme: nový výraz otevře nové způsoby vnímání a myšlení. Merleau-Ponty zde - podobně jako již ve Fenomenologii vnímání - kontrastuje ,̌reč, jíž se mluví“ (la parole parlée) na jedné straně a „promlouvající řeč“ (la parole parlante) na straně druhé. ${ }^{3}$ Naprríč kapitolami Prózy světa Merleau-Ponty zkoumá možnosti tvůrčího výrazu v oblasti poezie, literatury a malby, kontrastuje je $\mathrm{s}$ formalizovaným užitím jazyka $\mathrm{v}$ algoritmech a v závěru tematizuje vztah mezi tvůrčí malbou a dětskou kresbou.

Kapitola Vnímání druhého a dialog se od tématu řeči obrací k otázce, jaká představa o mezi-lidském setkávání je předpokladem filosofie řeči rozvíjené v knize Próza světa. U Merleau-Pontyho přitom nejde o jediný text $\mathrm{k}$ tématu intersubjektivity. Již dříve mu věnoval samostatnou kapitolu ve Fenomenologii vnímání, ${ }^{4}$ jednu promluvu v řadě rozhlasových přednášek v roce $1948^{5}$ a zhruba v době práce na Próze světa se na ně

1 Viz M. Merleau-Ponty, Vnímání druhého a dialog, str. 125-137 v tomto čísle časopisu.

2 Viz. C. Lefort, Avertissement, in: M. Merleau-Ponty, La prose du monde, Paris 2008, str. vi.

3 Viz např. M. Merleau-Ponty, Fenomenologie vnímání, přel. J. Čapek, Praha 2013, str. 249. V podobném smyslu M. Merleau-Ponty, La prose du monde, str. 17 (le langage parlé et le langage parlant).

4 Kap. Druhý a lidský svět, in: M. Merleau-Ponty, Fenomenologie vnímání, str. 419-441.

5 M. Merleau-Ponty, Svět vnímání, přel. K. Gajdošová, Praha 2008, V. předn. Člověk z vnějšího pohledu, str. 45-56. 
opakovaně zaměřuje ve svých přednáškách na Sorbonně v letech 1949 až 1952. ${ }^{6}$ Analýza vztahu k druhému zaujímá ústřední místo také v textu $F i$ losof a jeho stín z roku $1959^{7}$ a objeví se na důležitém místě i v posmrtně vydaném, nedokončeném díle Viditelné a neviditelné. ${ }^{8}$ Uvedená pojednání o problematice intersubjektivity jsou vnitřně těsně provázaná. Pro pojetí intersubjektivity, které v nich Merleau-Ponty rozvíjí, je určující přesvědčení, že prvotní a nepřekročitelnou zkušeností života s druhými je sdílení téhož světa.

Vezměme si např́klad výraz bolesti ve tváři druhého člověka. Pro Merleau-Pontyho bolest nutně není privátní, nesdělitelná zkušenost, která se nikdy nemůže stát mou vlastní bolestí, nýbrž je naopak něčím, čemu mohu rozumět a skrze co se druhý otevírá mně i já jemu. Bolest je něčím, co máme společné, nakolik máme podobně uzpůsobená těla a podobně osvojené praktiky tělesného chování. Merleau-Ponty např́íklad upozorňuje na fenomény raného dětského transitivismu, kdy dítě „na matce vyžaduje, aby je chlácholila kvůli bolestem, jimiž trpí ona“. 9 Podobně i v dospělosti se opíráme o bezprostřední srozumitelnost pohybů či „gest" druhých lidí. Ve výše publikovaném textu Merleau-Ponty uvádí příklad, kdy pozorujeme muže spícího na slunci, který se probouzí a natahuje ruku po klobouku. K tomuto příkladu přidává komentář: „V okamžiku, kdy se muž probouzí na slunci a napřahuje ruku po svém klobouku, se mezi sluncem, které mě pálí a nutí mě přimhouřit oči, a gestem, které odtamtud z dálky přináší úlevu mé únavě, mezi tamtím rozpáleným čelem a gestem ochrany, jehož se u mne dovolává, utvořilo pouto, aniž bych musel o něčem rozhodovat." ${ }^{10}$ Takový popis vyzdvihuje sepětí mezi mnou a druhým, které je nezávislé na mé vůli a které se zakládá na tom, že určitý typ chování je pro nás typický či dokonce obecný.

Na některých místech se Merleau-Ponty záměrně přesouvá od popisu, jenž v uvedené situaci vidí vztah já - ty (a klade si otázku, zda a jak dobře se mohu vpravit do prožitků druhého), k popisu, jenž zde spatřuje nikoli dva oddělené lidi, nýbrž jeden jediný typ pohybu či zkušenosti,

6 Viz týž, Psychologie et pédagogie de l'enfant. Cours de Sorbonne 1949-1952, Lagrasse 2001, např. str. 38-48 a 539-570.

7 Týž, Filosof a jeho stín, přel. J. Fulka, in: K. Novotný (vyd.), Co je fenomén? Husserl a fenomenologie ve Francii, Červený Kostelec - Praha 2010, str. 85-110.

8 Týž, Viditelné a neviditelné, přel. M. Petř́čcek, Praha 2004, str. 143-145.

9 Týž, Filosof a jeho stín, str. 98. Podobné př́íklady viz také in: týž, Fenomenologie vnímání, str. 425; a týž, Svět vnímání, 51 n.

10 Viz str. 129-130 v tomto čísle časopisu. 
který si nachází různé instance. V souvislosti s prožitkem žalu, který vidím na tváři druhého, Merleau-Ponty přímo praví: žal můj i žal druhého jsou „variace bytí ke světu“, které se mohou „vkládat jak do chování druhého... tak do mého vlastního chování" ${ }^{11}$ Podobná vyjádření vyvolávala u Merleau-Pontyho čtenářu podezření, že Merleau-Ponty ztrácí ze zřetele odlišnost konkrétních jedinců ve prospěch monismu ne-osobních, anonymních struktur, ve prospěch sdílení téže tělesnosti a kultury. Výstižné vyjádření těchto pochybností formuloval např. R. Barbaras, když pravil: „Merleau-Ponty má pravdu oproti Husserlovi a Sartrovi, když zdůrazňuje zkušenost harmonie spíše než zkušenost objektivace a konfliktu; ale zdá se, že tímto směrem zachází příliš daleko, když rozpouští harmonii v obecnosti, v níž se už nikdo s nikým nesetkává, protože nikdo už nerozpoznává sebe sama. "12 O něco razantněji formuluje svou kritiku E. Lévinas, když u Merleau-Pontyho nachází „,anti-humanistickou či ne-humanistickou tendenci vztahovat lidství k ontologii anonymního bytíi“. Po této poznámce následuje rozhořčený výpad: „Tato tendence charakterizuje celou epochu, která ve svých úvahách o antropologii nedůvěřuje lidství. Čím více je určitá nauka lhostejná vůči osobním dramatům, tím lépe je obhajitelná.“"13 Merleau-Ponty skutečně uznává, že nakolik se omezíme na tuto anonymní a obecnou vrstvu zkušenosti, nelze mluvit o setkávání s druhým. Poukaz na ni ovšem nechce považovat za vyčerpávající popis setkávání s druhými, pouze za upozornění na jednu z nezbytných složek takového setkávání. Sám ostatně uvádí, že ,zde máme jen druhou živou bytost, ještě ne druhého člověka“" ${ }^{14}$ aby vzápětí sledoval ty rysy zkušenosti, díky nimž je naše zakoušení vždy výlučně naše vlastní, „solipsistické“. Nejedná se přitom o teoretický solipsismus, který by popíral existenci druhých, nýbrž o ,žitý solipsismus“, který počítá s jejich existencí, aby se vůči ní vztahoval v komunikaci či uzavíral do osamění, o ,solipsismus mnohých““. ${ }^{15}$

Co nového vnáší do těchto úvah zde vydávaný text Vnímání druhého a dialog? Přinejmenším dva postřehy. Zaprvé zřetelněji než jiné texty upozorňuje na skutečnost, že blízkost druhého, již zakouším pří

11 Týž, Fenomenologie vnímání, str. 430.

12 R. Barbaras, Vnímání. Esej o smyslově vnímatelném, přel. J. Fulka, Praha 1998, str. 32.

13 E. Lévinas, De l'intersubjectivité. Notes sur Merleau-Ponty, in: týž, Hors sujet, Paris 1987, str. 149.

14 M. Merleau-Ponty, Fenomenologie vnímání, str. 427.

15 Tamt., str. 432 a 434. 
sdílení téhož světa, není nutně harmonická. Pokud platí, že druhý není proti mně, ale „na okraji toho, co vidím a slyším, je na mé straně, po mém boku či za mnou“ " ${ }^{16}$ nemusí být přítomnost druhého nutně zdrojem uklidnění a jistoty. Druhý je naopak absolutně nezávislý, ${ }^{17}$ aniž bych tuto nezávislost mohl uchopit $\mathrm{v}$ podobě tváře, která vystupuje přede mnou, či protivníka, který maří mé záměry. Zadruhé tento text ličí setkání s druhým jakožto jiným jako zkušenost, na jejímž počátku je ztráta orientace a jejímž výsledkem je stávání se jiným: ,„pokud je druhý skutečně druhým, musím být v jistém okamžiku překvapen a dezorientován. Musíme se setkávat již nikoli v tom, $\mathrm{v}$ čem jsme si podobní, ale také v tom, v čem se lišíme. To předpokládá jistou proměnu mne samého jakož i druhého. " ${ }^{18} \mathrm{~V}$ souladu s projektem knihy Próza světa jsou tyto souvztažné proměny popsány jako naše společná účast na tvůrčím, živém dění řeči, na dialogu. Tuto účast na „promlouvající řeči“ lze ze strany mluvčího zakoušet jako zápolení o výraz, jako snahu o nebanální promluvu, v níž se odehrává a skrze niž se uchovává soužití nás jakožto nezaměnitelných jedinců. Ze strany naslouchajícího se jeví jako zprvu nesrozumitelné a dezorientující vyjádření, které má moc „otevřít nás jinému smyslu“. ${ }^{19}$ Kapitola Vnímání druhého a dialog ukazuje, že Merleau-Ponty nezakládá mezilidské vztahy ani na harmonii, v níž se vytrácejí rozdíly mezi jednotlivci, ani na anti-humanistické vizi, která nemá smysl pro osobní dramata, nýbrž na transformativních zkušenostech, které jsou bytostně řečové.

Jakub Čapek

\footnotetext{
16 Str. 127 v tomto čísle časopisu.

17 „Druhý existuje za námi stejně jako věci, jež nabývají absolutní nezávislost na okraji našeho vizuálního pole.“ Tamt., str. 131.

18 Tamt., str. 134.

19 Tamt., str. 135.
} 